\title{
A mother with complete absence of breast milk due to ectodermal dysplasia
}

A C D De Alvvis ${ }^{1}$, C Weerasinghe ${ }^{2}$

Sri Lanka Journal of Child Health, 2004; 34: 98-9

(Key words: ectodermal dysplasia, absence of breast milk)

Complete absence of secretion of breast milk due to an anatomical, physiological or pathological cause is rare. Congenital hypoplasia of breasts, Sheehan syndrome due to anterior pituitary failure following post-partum haemorrhage and bilateral mastectomy are some important rare causes. We report a mother with complete absence of breast milk due to hypohidrotic type of ectodermal dysplasia.

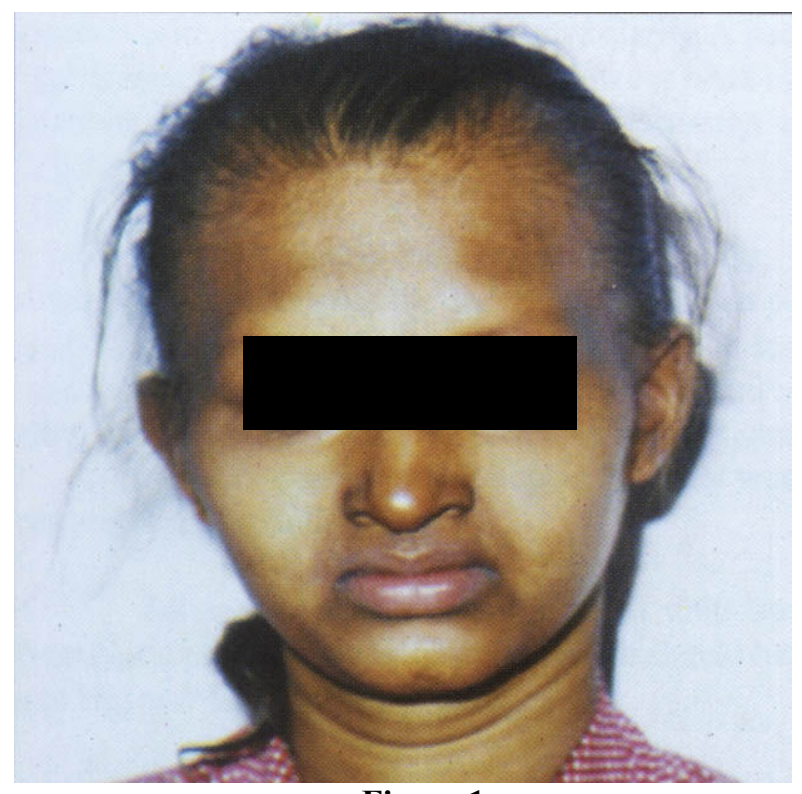

Figure 1

Face showed frontal bossing, malar hypoplasia, flattened nasal bridge, recessed columella, thick everted lips, and hyperpigmented periorbitai skin. Her entire body skin was dry without secretion of sweat and she complained of feeling feverish on warm days. Scalp hair was sparse, fine, unruly and

${ }^{1}$ Consultant $\begin{gathered}\text { Paediatrician, General Hospital, } \\ \text { Ratnapura, }\end{gathered}{ }^{2}$ Medical Officer, Cancer
Maharagamatute,

(Received on 25 April 2005)

\section{Case report}

A nineteen year old unmarried mother from a remote village in Mahiyangana delivered her second baby, a boy weighing $2100 \mathrm{~g}$, at term following an uneventful pregnancy. Her first baby delivered at 26 weeks of gestation had died soon after birth. Examination of the newborn was normal; however the mother complained of complete absence of breast milk. Examination of mother revealed the following. (Figures 1 and 2).

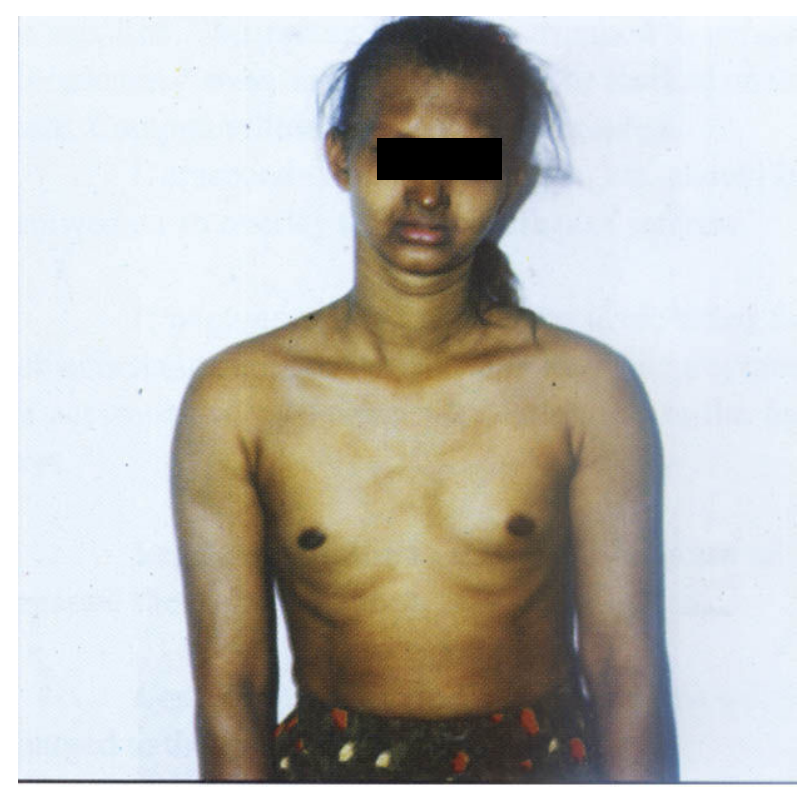

Figure 2

hypopigmented while eyebrows and eyelashes were absent. She only had a couple of teeth which were widely spaced and peg shaped. Her breasts were hypoplastic with no evidence of secretion of milk. She was born to non-consanguineous parents and examination of her fourteen year old paternal aunt's daughter also revealed similar features.

The above findings suggested a diagnosis of hypohidrotic type of ectodermal dysplasia and as the mother did not have breast milk the newborn was started on an infant formula. 


\section{Discussion}

Ectodermal dysplasia is a rare group of inherited disorders characterised by aplasia or dysplasia of tissues of ectodermal origin, such as teeth, skin, and appendageal structures including hair, nails, sweat and sebaceous glands ${ }^{1}$. A detailed classification of these syndromes has been produced recently ${ }^{2}$. The most common, classic type is hypohidrotic ectodermal dysplasia (HED), also known as Christ Siemens Touraine syndrome, previously reported in children by BJC Perera in $1972^{3}$. It is characterised by a triad of hypohidrosis, hypotrichosis and hypodontia ${ }^{1}$. The clinical features of our patient suggest this diagnosis. It is inherited commonly as an $\mathrm{X}$-linked recessive trait with the gene carried in the female and manifested in the male ${ }^{4}$. However, an autosomal recessive type of inheritance is also reported in certain families ${ }^{2}$. Hypoplastic or absent mammary gland is a well described feature of carrier females with $\mathrm{HED}^{2}$. This case reiterates the fact that mammary gland is a modified sebaceous gland and identifying patients with ectodermal dysplasia in the antenatal period makes anticipation of the problem with breast feeding possible.

\section{References}

1. Campbell A G M, Mclntosh N. editors, Forfar and Arneil's Textbook of Paediatrics; 4th ed. Edinburgh: Churchill Livingstone 1992; 1701- 2.

2. Freire-Maia N, Pinheiro M. editors, Ectodermal dysplasias: a clinical and genetic study New York: Alan R Liss 1984.

3. Perera B J C. Christ Siemens syndrome. Ceylon Journal of Child Health 1972; 3: 49-54.

4. Clarke A, Phillips D I, Brown R et ai Clinical aspects of $\mathrm{X}$ linked hypohidrotic ectodermal dysplasia. Arch Dis Child 1987: 62 : 989 
